Acta Universitatis Nicolai Copernici • Pedagogika XLI/1/2021

Nauki Humanistyczno-Społeczne • Zeszyt 453

DOI: http://dx.doi.org/10.12775/AUNC_PED.2021.004

\author{
Katarzyna Borawska-Kalbarczyk \\ Uniwersytet w Białymstoku \\ ORCID: 0000-0003-4315-2226
}

\title{
UCZEŃ W CYFROWEJ PRZESTRZENI INFORMACJI - \\ O (NIE)OBECNEJ EDUKACJI MEDIALNEJ
}
A Student in the Digital Information Space - About (not) Current Media Education

\begin{abstract}
Streszczenie
Celem artykułu jest przedstawienie wybranych problemów procesu użytkowania informacji cyfrowych przez uczniów w kontekście zjawiska nadmiaru informacji. Artykuł przedstawia zjawisko przeciążenia informacyjnego i jego konsekwencje. Postawiona jest teza, że źródłem trudności wykorzystywania informacji są niewystarczające kompetencje informacyjne młodzieży pokolenia cyfrowego. Przedstawione w artykule kompetencje informacyjne, jak również złożoność współczesnego cyfrowego środowiska powodują konieczność wzmocnienia procesu kształcenia kompetencji medialnych uczniów. W zakończeniu podjęta jest dyskusja dotycząca problemów i postulatów kształcenia z zakresu edukacji medialnej w polskim systemie edukacyjnym.

Słowa kluczowe: przeciążenie informacyjne, informacje cyfrowe, kompetencje informacyjne, edukacja medialna
\end{abstract}




\begin{abstract}
The aim of the article is to present selected problems of the process of using digital information by students in the context of the phenomenon information overload. The article presents the phenomenon of information overload and its consequences. The text presents a thesis that the source of difficulties in using information is the insufficient information literacy of young people from the digital generation. The information literacy presented in the article, as well as the complexity of the modern digital environment, make it necessary to strengthen the process of educating media competences. At the end, there is a discussion on the problems and postulates from the area of media education in the Polish educational system.
\end{abstract}

Ke y w o r d s : information overload, digital information, information literacy, media education

\title{
Wprowadzenie
}

7 apoczątkowana w ubiegłym wieku sieć internetowa, traktowana początkowo jako technologia rewolucyjna, o wąskim zakresie oddziaływania i innowacyjna, z rozmachem i dynamizmem zawładnęła wszystkimi dziedzinami życia człowieka. Znacząco wpłynęła na postrzeganie rzeczywistości i proces funkcjonowania w społeczeństwie. Trudno dostrzec moment, w którym Internet i towarzyszące mu cyfrowe technologie stały się nieodłącznymi towarzyszami naszego życia, oddziałując w obszarze kultury, edukacji, gospodarki, czy komunikowania się. Można zauważyć, że przestrzeń cyfrowa skolonizowała także sfery do niedawna utożsamiane z wymiarem czysto ludzkim, takie jak relacje, tożsamość, emocje lub mentalność. Internet jako niezwykle ekspansywne medium ewoluował on od początków swego istnienia, przechodząc od fazy medium elitarnego, zarezerwowanego dla wąskiej grupy informatyków do fazy medium masowego. Dynamiczny rozwój Internetu doprowadził do rewolucji w zakresie tworzenia, rozpowszechniania i odbioru informacji w postaci cyfrowej, modyfikując sposób działania całego społeczeństwa. Tym samym, masowa informatyzacja potwierdziła zapowiedzi Petera Druckera, że informacja stanie się 
najbardziej pożądanym zasobem XXI wieku1 ${ }^{1}$ Znaczenie i pozycja informacji uległa radykalnej zmianie, stała się ona jednym z cenniejszych towarów współczesnych formacji społecznych. Wypracowana przez Claude'a Shannona teoria informacji

„stworzyła pomost między informacją a niepewnością, pomiędzy informacją a entropią, informacją a chaosem. Doprowadziła do powstania dysków kompaktowych i faksów, komputerów i cyberprzestrzeni, prawa Moore'a i »krzemowych dolin« [...] Pojawiło się przetwarzanie informacji, a także jej magazynowanie i odzyskiwanie. Ludzie zaczęli nazywać nowe czasy erą informacji, podobnie jak wcześniej mówili o erach żelaza i pary wodnej"2.

Należy uznać, że informacja zyskała rangę siły modyfikującej funkcjonowanie współczesnych społeczeństw. Bez wątpienia postrzegać ją można jako istotny czynnik rozwoju kreatywności i innowacyjności, jest komponentem budowania wiedzy w procesie uczenia się, umożliwiając poprawę wielu sfer aktywności ludzkiej. Pomimo niezaprzeczalnych wartości i znaczenia informacji nie można pominąć negatywnych aspektów związanych z jej masowym charakterem i cyfrową formą. W przestrzeni Internetu w oszałamiającym tempie namnażają się niezliczone liczby danych trudne obecnie do wyrażenia w matematycznych jednostkach miary. Oprócz informacji wartościowych i prawdziwych cyfrowa sieć stała się źródłem treści sprzecznych, nierecenzowanych, nieselekcjonowanych o wątpliwej wartości poznawczej. Mimo świadomości, że to Internet przyczynił się w największym stopniu do powstania informacyjnego zalewu, trudno zanegować jego rangę jako podstawowego źródła informacji, wykorzystywanego w celu zaspokojenia prawie każdej informacyjnej potrzeby człowieka. Przekonanie to podzielają zwłaszcza młodzi użytkownicy wirtualnej przestrzeni, dla których media cyfrowe są naturalnym miejscem codziennych aktywności. Nieograniczone możliwości archiwizowania i dystrybuowania zróżnicowanych rodzajów treści otworzyły nowy wymiar ich aktywności poznaw-

1 P. Drucker, Zarządzanie w XXI wieku, Warszawa 2000.

2 J. Gleick, Informacja, bit, wszechświat, rewolucja, Kraków 2012, s. 13. 
czej. Intensywne zanurzenie młodych ludzi w przestrzeni wirtualnej przyczyniło się do zmiany stylu zdobywania i przetwarzania informacji. Dotychczasowy, żmudny proces przeszukiwania zasobów papierowych został zastąpiony - błyskawicznym i pozornie łatwym eksplorowaniem informacyjnych źródeł cyfrowych. Koszt dostępu do informacji został zminimalizowany do poziomu niemal zerowego, jednak tym samym podnosząc niewspółmiernie koszty sensownego ich selekcjonowania i wykorzystania. W opinii Dariusza Jemielniaka ${ }^{3}$ „rewolucja internetowa unaoczniła ciekawe zjawisko: wielu ludzi wyraźnie preferuje szybkość i wygodę dostępu do informacji, przedkładając je nad jakość, weryfikowalność czy wiarygodność". Digitalizacja społeczeństwa przyczyniła się do wykreowania specyficznego świata, który - z jednej strony stwarza możliwości dostępu do potężnych zasobów informacyjnych, sprzyja również powstaniu zagrożeń wynikających z niewystarczających kompetencji informacyjno-medialnych użytkowników.

Celem artykułu jest przedstawienie wybranych problemów procesu użytkowania informacji cyfrowych przez uczniów w kontekście zjawiska nadmiaru informacji. W rozwinięciu czynię starania udowodnienia tezy, że źródłem trudności i ograniczeń pozyskiwania i wykorzystywania informacji są niewystarczające kompetencje informacyjne młodych z pokolenia cyfrowego, jak również niedostateczna jakość procesu wychowania informacyjnego. Troskę o kształtowanie obu wymienionych kategorii (tak kompetencji informacyjnych, jak i wychowania informacyjnego) uznaję za istotny komponent edukacji medialnej. W zakończeniu podjęta zostanie dyskusja dotycząca problemów i postulatów kształcenia z zakresu edukacji medialnej w polskim systemie edukacyjnym.

\section{Przeciążenie informacyjne - zarys problemu}

Głównym zagadnieniem w kontekście problematyki artykułu jest zjawisko nadmiaru informacji. Z uwagi na swoją wielowymiarowość i skutki poznawcze współwystępuje z innymi kategoriami pojęciowymi, takimi jak: informacyjne zmęczenie, infostres, niepokój informa-

3 D. Jemielniak, Socjologia Internetu, Warszawa 2019, s. 24-25. 
cyjny czy przeciążenie informacyjne. Ten ostatni termin został po raz pierwszy użyty przez futurologa Alvina Tofflera w 1970 r., w książce „Szok przyszłości”, kiedy to przewidział, że gwałtowny wzrost ilości informacji może wywołać znaczące problemy wśród jej odbiorców. Inne źródła podają, że niebezpieczne następstwa zalewu informacyjnego było zauważone w 1963 r. przez amerykańską historyk Elisabeth Eisenstein. Przeciwstawiając się opinii o zagrożeniu utratą pamięci ludzkości (ostrzeżenia Amerykańskiego Towarzystwa Historycznego), wyraziła opinię w kontekście rozwoju technologii informacyjnych, iż „w epoce, w której odszyfrowano pismo linearne B i odkryto zwoje znad Morza Martwego raczej nie ma większego powodu, by troskać się o »utratę pamięci przez ludzkość«. Za to można się niepokoić przeciążeniem jej obwodów”. Sformułowanie „przeciążenie obwodów” było nowatorską metaforą na wyrażenie odczucia nadmiaru informacji ${ }^{5}$.

Negatywne konsekwencje doświadczania nadprodukcji informacji dobrze ilustrują zjawiska ujęte przez Marshalla McLuhana w postaci jednego z czterech praw mediów. W świetle pierwszych trzech każdy wytwór człowieka wzmacnia jego zdolności bądź przyspiesza pewne procesy; inne eliminuje lub uznaje za przestarzałe oraz pozwala na odzyskanie przeszłości. W myśl czwartego prawa „wraz z osiągnięciem wartości krytycznej każde zjawisko przekształca się w swe przeciwieństwo"6. W kontekście zjawiska nadprodukcji informacji zwraca tu uwagę właśnie prawo odwrócenia - łatwość wytwarzania danych we współczesnym świecie skutkuje więc informacyjnym zalewem, którego bezpośrednim następstwem może być przeciążenie informacyjne. Jest to jeden z terminów opisujących stany, jakich doświadcza człowiek w sytuacji konfrontacji z nadmiarową ilością informacji, przekraczającą jego możliwości percepcyjne. Wśród przyczyn przeciążenia informacyjnego wskazuje się: niekontrolowany wzrost liczby produkowanych nowych informacji; ogromną łatwość powielania i przekazywania informacji przez media cyfrowe; wzrost pojemności istniejących kanałów

4 J. Gleick, Informacja, bit, wszechświat, s. 371.

5 Tamże, s. 372.

${ }^{6}$ K. Loska, Dziedzictwo McLuhana - między nowoczesnością a ponowoczesnością, Kraków 2001, s. 88. 
przekazu informacji cyfrowej; sprzeczność i niedokładność dostępnych informacji; niską świadomość informacyjną nadawców i odbiorców informacji; brak efektywnych metod porównywania i przetwarzania różnych rodzajów informacji; fragmentaryzację informacji ${ }^{7}$.

Namysł nad deficytem jakości informacji, jako wskazanej wyżej przyczyny przeciążenia informacyjnego, prowadzi do wyróżnienia jej pożądanych, jak i niepożądanych cech. Wśród licznych propozycji pozytywnych atrybutów informacji rozpatrywanych w kontekście jej jakości można wymienić: aktualność, rzetelność, dokładność, kompletność, jednoznaczność, komunikatywność, elastyczność, relewantność Procesy masowego rozprzestrzeniania się informacji i niekontrolowany dostęp do wielu jej źródeł sprawiają, że osłabieniu ulegają poznawcze mechanizmy merytorycznej oceny, a wiarygodne i rzetelne informacje mogą być zmarginalizowane przez treści o wątpliwej wartości. Charakterystyki te są jednymi z wielu atrybutów opisywanych jako tzw. cechy niepożądane. Przegląd cech takiego rodzaju dokonuje Bogdan Stefanowicz, wymieniając: fragmentaryczność, ogólnikowość, rozwlekłość i niejednoznaczność informacjị.

Proces przeciążenia informacyjnego można analizować w wymiarze tak subiektywnym, jak i obiektywnym. Subiektywne przeciążenie informacji odnosi się do stanu postrzeganego przez jednostkę, a wymiar obiektywny definiowany jest przez rzeczywiste przeładowanie informacji, którego wymierną stroną jest liczba i rodzaj pozyskiwanych źródeł i informacji ${ }^{10}$. Zdaniem Erica Schmidta z korporacji Google obecnie co 2 dni wytwarzamy tyle danych, ile cała ludzkość wyprodukowała od początku cywilizacji do początku XXI wieku. Liczba ta ulega co najmniej podwojeniu w rytmie dwuletnim. Szacuje się, że

7 W. Babik, O natłoku informacji i związanym z nim przeciążeniu informacyjnym, w: Człowiek, media, edukacja, red. J. Morbitzer, Kraków 2010, s. 21-27.

8 B. Stefanowicz, Informacja, Warszawa 2010, s. 95-100.

9 Tamże, s. 103-105.

10 M. J. Eppler, J. Mengis, The concept of information overload: A review of literature from organization science, accounting, marketing, MIS, and related disciplines, "Information Society", 2004 tom 20(5), s. 325-344, podaję za: J. Światowiec-Szczepańska, Zjawisko przeciążenia informacyjnego $w$ procesach decyzyjnych menedżerów, „Studia Oeconomica Posnaniensia”, 2018 nr 11, s. 63. 
obecnie na świecie jest 3,2 zetabajtów danych, a do 2020 roku liczba ta urośnie do 40 zetabajtów ${ }^{11}$. Trwająca pandemia koronawirusa tym bardziej zwielokrotniła liczbę produkowanych i przesyłanych informacji drogą kanałów cyfrowych, co m. in. przyczyniło się do powstania zjawiska ,infodemii” ${ }^{2}$.

\section{Wybrane trudności procesu odbioru informacji cyfrowych}

Obserwowane współcześnie przeładowanie informacyjne wraz z dewaluacją jakości informacji, wyrażającą się we wskazanych wyżej niepożądanych atrybutach mogą stać się źródłem trudności w procesie odbioru i przetwarzania informacji, zwłaszcza przez użytkowników o niewystarczających kompetencjach poznawczych. Problemy pojawiające w procesie swoistego „konsumowania informacji” można identyfikować wielorako, np. jako trudności w samym początkowym zakresie realizowania potrzeby informacyjnej, tj. wyboru właściwego źródeł informacji, przez trudności dokonywania selekcji informacji i podjęcia decyzji o prawdziwości informacji. Maria Ledzińska w badaniu dotyczącym doświadczania stresu informacyjnego wymienia następujące: „trudności w koncentrowaniu uwagi, trudności w selekcjonowaniu informacji, trudności w planowaniu uczenia się, trudności w integrowaniu bieżących informacji z dotychczasową wiedzą, trudności w przekształcaniu informacji $\mathrm{w}$ wiedzę, dyskomfort związany $\mathrm{z}$ poczuciem dezaktualizowania się wiedzy, trudności w ocenie stanu własnej wiedzy, trudności w przypominaniu sobie potrzebnych informacji, trudności w wykorzystywaniu informacji w codziennym życiu"13.

11 Big Data - duże liczby, nowe możliwości, nowe narzędzia, https://skuteczneraporty.pl/blog/big-data-duze-liczby-nowe-mozliwosci-nowe-narzedzia [dostęp: 10.03.2021].

12 Zob. m.in. T. Goban-Klas, Media w płynnej pandemii 2020. Komunikacja w czasie lockdownu: oddzielnie, ale razem, „Studia Medioznawcze”, $2020 \mathrm{nr} 4$.

13 M. Ledzińska, Rola inteligencji poznawczej i emocjonalnej $w$ dobie nadprodukcji informacji, „Annales Universitatis Mariae Curie-Skłodowska Lublin-Polonia”, 2005 vol. XVIII, Sectio J, s. 17. 
Wymienione kategorie uświadamiają, jak wysoce złożony jest problem funkcjonowania w świecie nadmiaru informacji, czego trafnym podsumowaniem jest refleksja Herberta Simona:

„W świecie informacyjnym bogactwo informacji oznacza ubóstwo czego innego: niedostatek czegoś, co ta informacja pożera. Odpowiedź na to pytanie, co zabiera informacja, jest raczej oczywista: zabiera uwagę odbiorców. Dlatego bogactwo informacji skutkuje niedostatkiem uwagi i potrzebą efektywnego dzielenia tej uwagi między mogącymi ją pochłonąć wieloma źródłami informacji”"14.

Współczesna młodzież, definiowana jako iGeneracja ${ }^{15}$ równolegle żyjąca w cyfrowym świecie, w procesie użytkowania informacji cyfrowych doświadczać może problemu wyboru informacji i oceny ich wiarygodności. Dostrzega się, że młodzi użytkownicy sieci, mając dostęp do coraz większej liczby informacji, jedynie powierzchownie prześlizgują się po ich zasobach, co skutkuje spłyconym zrozumieniem i niewłaściwym wykorzystaniem zdobytych wiadomości. Na taki typ wykorzystywania zasobów Internetu wskazuje Tomasz Goban-Klas ${ }^{16}$, definiując surfowanie jako niską formę aktywności informacyjnej. Taki styl zgłębiania określonych treści stoi w sprzeczności z metodą koła hermeneutycznego, co zauważa Manfred Spitzer: „cyfrowi tubylcy nie poruszają się po tym hermeneutycznym kole poznania - klikają przez jakiś czas na oślep i nigdy nie wracają do rzetelnego źródła danych; szukają informacji w sposób horyzontalny (poruszają się po powierzchni), a nie wertykalnie (nie zgłębiają się)"17, co skutkuje spłyconym zrozumieniem i niewłaściwym wykorzystaniem zdobytych wiadomości,

${ }^{14}$ H. Simon, A Designing Organizations for an Information-Rich World, w: Computers, Communications, and the Public Interest, red. M. Greenberger, Baltimore 1971, s. 6-7, https://zeus.zeit.de/2007/39/simon.pdf [dostęp: 12.03.2021].

15 Zob. J.M. Twenge, iGen, Sopot 2019.

16 T. Goban-Klas, Surfowanie czy żeglowanie w cyberprzestrzeni, czyli o wychowaniu człowieka medialnego i mobilnego, w: Polskie doświadczenia w kształtowaniu społeczeństwa informacyjnego: dylematy cywilizacyjno-kulturowe, red. L. Haber, Kraków 2002, s. 43.

17 M. Spitzer, Cyfrowa demencja, Słupsk 2013, s. 186. 
jak również trudnością w przekształcaniu zdobywanych informacji w użyteczną wiedzę. Wskazana trudność ma swoje uwarunkowania neurologiczne, wynikające z niekorzystnego oddziaływania cyfrowych technologii na procesy poznawcze. Maggie Jackson dostrzega, że tworzą one „kulturę społecznego rozproszenia, intelektualnej fragmentaryzacji, zmysłowego oddzielenia. Gubimy w niej zdolność do zachowania uwagi i koncentracji”"18. Styl poznawczy młodego pokolenia można nazwać rozgorączkowanym - technologie cyfrowe dopingują w domaganiu się wszystkiego w trybie „natychmiast”, a refleksyjne myślenie zastępowane jest przez błyskawiczny i powierzchowny przegląd szybko zmieniających się patchworkowych treści.

Możliwość ulokowania w sieci przez każdego jej użytkownika właściwie wszystkiego - od tekstu przez zdjęcia, czy filmy - przyczynia się do inflacji jakości informacji. Współcześnie to media społecznościowe rywalizują z prasą papierową i portalami informacyjnymi $\mathrm{w}$ pełnieniu funkcji podstawowego źródła informacji o świecie, a uprzywilejowane miejsce bezsprzecznie zajmuje Facebook. W świetle raportu z badań „Bezpieczne wybory. Badanie opinii o (dez)informacji w sieci” wynika, że 56,1\% badanych jednoznacznie deklaruje, że ma zaufanie do treści publikowanych w Internecie. Spośród wszystkich mediów społecznościowych, ufający Internetowi użytkownicy najczęściej korzystają z Facebooka i YouTube. Jednocześnie badani szacują, że około 30\% wszystkich treści jest poddana manipulacjom dezinformacyjnym. Raport wskazuje, że ponad połowa ankietowanych $(56,2 \%)$ spotkała się ze zjawiskiem dezinformacji w sieci. Nieprawdziwe, sfabrykowane treści w Internecie dostrzega 23,9\% badanych użytkowników sieci ${ }^{19}$.

Ważne wydaje się także zwrócenie uwagi na umiejętność oceny wiarygodności odbieranych informacji. Nadmierna produkcja cyfrowych treści wraz z ich rozproszeniem na wielu serwerach często uniemożli-

18 M. Jackson, Distracted: The Erosion of Attention and the Coming Dark Age, New York, Oxford 2008, s. 8.

19 M. Bochenek, R. Lange, Bezpieczne wybory. Badanie opinii o (dez)informacji w sieci, Warszawa 2019, https://www.nask.pl/pl/o-nask/eksperci-nask/publikacje-naukowe/1631,Badania-NASK-ponad-polowa-Polakow-styka-sie-z-manipula cja-i-dezinformacja-w-inte.html, s. 8 [dostęp: 28.05.2019]. 
wia skuteczną selekcję i wartościowanie docierających do odbiorcy informacji. Dodatkowo, dla wielu obecnych młodych cyfrowych tubylców to atrakcyjność informacji jest nadrzędna wobec jej własności merytorycznych. Korzystanie z informacji, których podstawowym źródłem jest Internet może mieć szczególnie negatywny wpływ na osoby niedojrzałe poznawczo, o niskim stopniu ukształtowania krytycyzmu myślenia. Niedostateczny poziom instrumentów selekcji informacji i krytycznej refleksji prowadzić może do niewłaściwego wartościowania informacji, zawężenia zainteresowań i spadku zdolności poznawczych.

Zachowania informacyjne $\mathrm{w}$ przestrzeni Internetu stały się podstawą wyróżnienia dwóch wzorów jednostek: adaptacyjnych i nieadaptacyjnych. Zachowania przejawiane w kontaktach z mediami elektronicznymi definiowane jako adaptacyjne cechują ludzi dostrzegających potrzebę wybierania informacji i umiejących je wybierać. Działania w wirtualnej przestrzeni określane jako nieadaptacyjne charakteryzują jednostki bezkrytyczne, z ograniczoną umiejętnością wybierania, poruszające się po sieci metodą wolnych skojarzeń ${ }^{20}$. Jak zauważają autorzy raportu „Młodzi i media” „kluczowym problemem dla wykorzystania Internetu jest kompetencja polegająca na trafnej ocenie jakości zdobytych informacji. O ile tradycyjne publikacje są niejako »umocowane « poprzez wskazanie wydawcy, który - przynajmniej teoretycznie - jest pewnym gwarantem jakości (poprzez publikowanie tekstów, które zostały pozytywnie zrecenzowane lub chociaż przeszły przez proces korekty redakcyjnej), publikacje Internetowe bywają efemeryczne, anonimowe czy też pozbawione jakiejkolwiek redakcji”21.

Aspekt wiarygodności i także obiektywizmu w stosunku do oferowanych rezultatów wyszukiwania ma wymiar nie tylko indywidualnych właściwości poznawczych. Firma Google od grudnia 2009 roku objęła wszystkich użytkowników programem spersonalizowanego wy-

20 M. Ledzińska, Rola inteligencji poznawczej i emocjonalnej, s. 20. Autorka do grupy jednostek nieadaptacyjnych zalicza ponadto zagorzałych przeciwników technologii informacyjnych, którzy identyfikują je z zagrożeniami i tym samym wyznają filozofię ich całkowitej negacji i odrzucenia.

21 M. Filiciak, M. Danielewicz, M. Halawa, P. Mazurek, A. Nowotny, Młodzi i media. Nowe media a uczestnictwo $w$ kulturze, Warszawa 2010, s. 115. 
szukiwania, co oznacza, że wyszukiwarka przestała kierować się obiektywnym algorytmem oceniającym tylko przeszukiwane strony - decyduje teraz subiektywna ocena, w sensie, na ile coś jest istotne dla danej osoby. Biorąc pod uwagę, iż do tej oceny dodawana jest lokalizacja, historia wyszukiwania i inne, znane tylko Google wskaźniki, skutkuje to tym, że dwie różne osoby otrzymają inne rezultaty ${ }^{22}$. Taka filozofię prezentowania treści w sieci, odbierająca tym samym podmiotowość jednostki, przyczyniła się do ukształtowania kultury cyfrowej, którą Magdalena Szpunar określa mianem jednostkocentrycznej ${ }^{23}$. Doświadczanie niewidzialnej z założenia selekcji informacji oferowanych przez algorytm wyszukiwarki - tego, co odbieramy i tego, czego nie możemy odebrać, w sytuacji nałożenia niskiej świadomości informacyjnej internautów rodzi ryzyko ugrzęźnięcia w treściach zgodnych z ich oczekiwaniami i wygodnymi poznawczo, co nie zawsze jest tożsame z informacjami wiarygodnymi. Sytuację tę opisuje zjawisko informacyjnej bańki zdefiniowane przez Eli Parisera w 2011 r. Według autora tego pojęcia filter bubble to osobiste i niepowtarzalne uniwersum informacyjne, w którym każde z nas żyje online. Pariser zauważa, że „bańka jest twoim własnym unikalnym informacyjnym wszechświatem, w którym żyjesz online. Zawartość bańki zależy od tego, kim jesteś i co robisz. Szkopuł w tym, że nie decydujesz o tym co trafia, a co ważniejsze, nie decydujesz także, co zostaje wycięte z wyników. [...] Zamiast zbalansowanej diety, możesz skończyć otoczonym przez śmieci informacyjne"24. W konsekwencji -

„świat w takiej optyce staje się zdecydowanie bardziej jednowymiarowy i zunifikowany, niż ma to miejsce w rzeczywistości. Funkcjonowanie w takiej przekłamanej, ale i w pewnym sensie narcystycznej rzeczywistości sprawia, że jednostka przestaje być zainteresowana konfrontowaniem swoich własnych przekonań z innymi, a każdą formę odmienności może nie tyle odrzucać, co nie dopuszczać do świadomości, gdyż narzuca się jej

22 W. Orliński, Internet. Czas się bać, Warszawa 2013, s. 70-72.

${ }^{23}$ M. Szpunar, Kultura algorytmów, Kraków 2019, s. 60.

24 E. Pariser, Uważaj na internetowe „bańki filtrujące”, https://www.ted.com/ talks/eli_pariser_beware_online_filter_bubbles/transcript?language $=\mathrm{pl} \# \mathrm{t}-9105$ [dostęp: 9.03.2021]. 
ujednoliconą wersję cyfrowej rzeczywistości, z którą w znaczącej mierze się utożsamia"25.

Zaufanie do Internetu przejawiane przez młodzież można zdefiniować w kategoriach „fenomenu osobowości w społeczeństwie informacyjnym"26. Kazimierz Wenta wskazuje, że użytkownikami sieci są osoby zorientowane na autokreację interpersonalną i komunikowanie się, a w mniejszym stopniu poszukujący informacji i pragnący poszerzania swojej wiedzy. Przejawiane przez nich zaufanie do Internetu wynika z posiadania określonego zestawu cech powiązanych w sposób bezpośredni z komunikowaniem ${ }^{27}$.

Niestety, przy doświadczanym współcześnie nadmiarze informacji i mnożenia się wielorakich źródeł ich nadawania oraz rozpowszechniania weryfikacja ich treści staje się coraz trudniejsza. Już w 2014 r. Światowe Forum Ekonomiczne wskazało gwałtowne rozprzestrzenianie błędnych informacji $\mathrm{w}$ Internecie jako jedną $\mathrm{z}$ dziesięciu najważniejszych tendencji zachodzących w nowoczesnych społeczeństwach ${ }^{28}$. Najbardziej jaskrawym przejawem informacji nieprawdziwych są pojawiające się w przestrzeni medialnej tzw. fake newsy. Według angielskiego "Collins Dictionary” termin fake news został słowem roku $2017^{29}$. Nazwę tę stosuje się do poszczególnych wpisów, wiadomości lub nawet całych kanałów, gdzie przesyłane dane okazują się być całkowicie nieprawdziwe lub (w różnym stopniu) sprzeczne z prawdą. Cechą charakterystyczną jest wątpliwość co do rzetelności przekazywanych treści oraz pojawianie się w mediach cyfrowych lub innych masowego przeka-

25 M. Szpunar, Kultura algorytmów, s. 62.

${ }^{26} \mathrm{~K}$. Wenta, Meandry zaufania do Internetu w nieprzychylnym świecie, w: Człowiek, media, edukacja, red. J. Morbitzer, E. Musiał, Kraków 2013, s. 435.

27 Tamże, s. 437.

28 Zwalczanie dezinformacji w Internecie: podejście europejskie, Komunikat Komisji do Parlamentu Europejskiego, Rady, Europejskiego Komitetu Ekonomiczno-Społecznego i Komitetu Regionów, 2018, http://data.consilium.europa.eu/doc/ document/ST-8578-2018-INIT/pl/pdf [dostęp: 10.05.2019].

29 Collins 2017 Word of the Year Shortlist, https://blog.collinsdictionary.com/ language-lovers/collins-2017-word-of-the-year-shortlist [dostęp: 17.03.2021]. 
$\mathrm{zu}^{30}$. W bardzo krótkim czasie właśnie środowisko mediów społecznościowych stało się „podziurawione różnymi formami cyfrowego zanieczyszczenia" ${ }^{\text {, }}$, do których Gian Fulgoni zalicza fake newsy. Fake news przypomina plotkę, „którą każdy chętnie dystrybuuje, mimo że nie jest pewien, czy jest ona prawdziwa. Sam fakt, że wystarczająco dużo ludzi przekazuje ją dalej wystarcza do tego, aby zacząć w nią wierzyć"32. Kontakt z fake newsami zniekształca system wiedzy odbiorców takich zmanipulowanych informacji, zwłaszcza tych o niskim stopniu krytycznego myślenia i jednocześnie wysokim poziomie zaufania do informacji cyfrowych. Jest to szczególnie niebezpieczne w sytuacji, gdy głównym źródłem informacji - a tak się dzieje w odniesieniu do młodych użytkowników sieci - są dla nich media społecznościowe. Proces selekcji, weryfikacji oraz kontroli treści jest wówczas zdominowany presją czasu, czego konsekwencją jest przyjmowanie wiadomości fałszywych za prawdziwe. Tę ostatnią przeszkodę $\mathrm{w}$ postaci braku czasu na poszukiwanie informacji, co skutkuje zapoznanie się z treścią informacji w sposób powierzchowny i podejmowanie decyzji niepopartej wnikliwą analizą sygnalizuje Hanna Batorowska. Równie ważna jest także bariera braku wiedzy, czego efektem jest niski poziom rozumienia sensu komunikatu i problemy z percepcją treści ${ }^{33}$. W opinii autorki -

„przeładowanie informacjami zniekształconymi tworzy atmosferę niepewności informacyjnej. Nieumiejętność lub niemożność oceny napływających komunikatów czy ich błędna interpretacja powodują, że informacja prawdziwa ginie $\mathrm{w}$ nadmiarze pozostałych, wnika w szum informacyjny; informacja nierelewantna sprawia zaś wrażenie wartościowej, potęgując u odbiorcy dyskomfort informacyjny i skutkując dezinformacją"34.

30 M. Waszak, Postprawda i fake news, „Refleksje”, 2017 nr 6, http://refleksje. amu.edu.pl/wp-content/uploads/2018/07/re_2017_16_12.pdf [dostęp: 19.03.2021].

31 G. Fulgoni, A. Lipsman, The Downside of Digital Word of Mouth and the Pursuit of Media Quality, "Journal of Advertising Research", 2017 t. 57, s. 127.

32 K. Bąkowicz, Wprowadzenie do definicji i klasyfikacji zjawiska fake newsa, „Studia Medioznawcze”, 2019 nr 3, s. 283.

33 H. Batorowska, R. Klepka, O. Wasiuta, Media jako instrument wpływu informacyjnego i manipulacji społeczeństwem, Kraków 2019, s. 54.

34 Tamże, s. 53. 
Na tym tle powstaje pytanie: czy i jakimi kryteriami powinni kierować się użytkownicy informacji cyfrowych w ich ocenie? Do podstawowych kryteriów oceny informacji Maria Nowina-Konopka zalicza użyteczność i wiarygodność, w obrębie których wskazuje kryteria szczegółowe. I tak uszczegóławiając kryterium podstawowe, jakim jest użyteczność, wyróżniła aktualność oraz zawartość (w jej obrębie wskazała formę, aktualność, relewantność, technikę, dostępność, hiperłącze i kompletność). Do kryteriów szczegółowych wiarygodności zostały użyte: bezpieczeństwo, poprawność, obiektywizm, cel i autorstwo ${ }^{35}$. $\mathrm{Z}$ podsumowania wyników dostępnych badań, dokonanym $\mathrm{w}$ raporcie „Information behaviour of the researcher of the future" przez British Library i JISC Study ${ }^{36}$ wynika, że na podstawie szybkości procesu wyszukiwania treści w Internecie przez młodych ludzi okazuje się, iż niewiele czasu poświęcają na ocenę informacji, zaś proces poszukiwania kończy się w momencie znalezienia treści, z pominięciem czynności ich studiowania. Młodzi z iGen niewiele uwagi poświęcają treści tekstu, zadowalając się jedynie jego obecnością/brakiem lub akceptując zbieżność słów pasujących do wyszukiwanych haseł. W celu potwierdzenia trafności zadowala ich także odpowiedni obraz graficzny. Należy zgodzić się z Bronisławem Siemienieckim, który zauważa, że kontakt młodzieży z informacją niskiej jakości skutkować będzie zdobywaniem stosownych do tej jakości doświadczeń, czego konsekwencją może być utrudniona wielostronność rozwoju czy zubożenie procesu podejmowanych działań w sferze społeczno-ekonomicznej37.

Podsumowując, w obliczu zjawiska Big Data w obszarze ważniejszych kompetencji współczesnego człowieka ${ }^{38}$ należy ulokować kompe-

35 M. Nowina-Konopka, Infomorfoza. Zarządzanie informacją w nowych mediach, Kraków 2017, s. 163-164.

${ }^{36}$ P. Williams, I. Rowlands, Information behaviour of the researcher of the future, https://edu.au.dk/fileadmin/www.dpu.dk/viden/temaeraaa/informationskompetence/subsites_informationskompetence_20100223144624_information-behaviour.pdf [dostęp: 17.03.2021].

37 B. Siemieniecki, Pedagogika kognitywistyczna. Studium teoretyczne, Kraków 2013, s. 166.

38 Zob. Zalecenie Rady Unii Europejskiej z dnia 22 maja 2018 r. w sprawie kompetencji kluczowych w procesie uczenia się przez całe życie, https://eur- 
tencje cyfrowe, a zwłaszcza informacyjne - w obrębie których mieszczą się umiejętności pozyskiwania, selekcji, analizy, wykorzystywania i tworzenia informacji.

\section{Kompetencje informacyjne - ujęcie teoretyczne}

Uznaje się, że pojęcie kompetencji informacyjnych zostało wprowadzone do naukowego dyskursu w 1974 r. przez Paula Zurkowskiego w raporcie „The Information Service Environment Relationships and Priorities" adresowanym do National Commission on Libraries and Information Science. P. Zurkowski zaprezentował w nim pogląd, że

„ludźmi kompetentnymi informacyjne można uznać osoby przeszkolone w zakresie wykorzystywania informacyjnych zasobów dla celów swojej pracy. Nauczyli się oni technik i umiejętności wykorzystywania złożonej gamy narzędzi informacyjnych i podstawowych źródeł $\mathrm{w}$ formułowaniu i rozwiązywaniu problemów informacyjnych. Jednostki z pozostałej części populacji, mimo posiadania umiejętności piśmienniczych i czytelniczych nie są w stanie dokonać miary znaczenia informacji, nie potrafią dopasować informacji do swoich potrzeb i realistycznie rzecz ujmując, muszą być uważani za analfabetów informacyjnych"39.

Pierwsze próby określenia information literacy mają źródło w działalności i badaniach organizacji bibliotekarskich. Jedną z wcześniejszych jest definicja Stowarzyszenia Bibliotek Amerykańskich (American Library Association, ALA) z 1989 roku, zgodnie z którą information literacy interpretowano jako zespół umiejętności niezbędnych do rozpoznania, kiedy informacja jest potrzebna oraz zlokalizowania, oceny i efektywnego wykorzystania potrzebnej informacji ${ }^{40}$. Współcześnie,

-lex.europa.eu/legal-content/PL/TXT/PDF/?uri=CELEX: 32018H0604(01)\&from=EN [dostęp: 17.03.2021].

39 W. Badke, Foundations of Information Literacy: Learning From Paul Zurkowski, 2010, https://www.researchgate.net/publication/293703989_Foundations of_information_literacy_Learning_from_paul_zurkowski [dostęp: 17.03.2021].

${ }_{40}$ Wskazana definicja information literacy zawarta w treści dokumentu Information Literacy Competency Standards for Higher Education była aktualna 
aby podkreślić dynamizm, elastyczność, rozwój indywidualny i uczenie się w społeczności, uznano, że information literacy to zestaw „zintegrowanych umiejętności obejmujących refleksyjne odkrywanie informacji, zrozumienie, w jaki sposób informacje są wytwarzane i wartościowane, oraz wykorzystanie informacji w tworzeniu nowej wiedzy i etycznym uczestnictwie w społecznościach uczących się ${ }^{\text {"41 }}$. Umiejętność korzystania z informacji obejmuje

„zestaw umiejętności i zdolności, których każdy potrzebuje do podjęcia zadań związanych z informacją takich, jak na przykład: poszukiwanie, uzyskiwanie dostępu, interpretowanie, analizowanie, zarządzanie, tworzenie, przechowywanie czy udostępnianie informacji. Obejmuje krytyczne myślenie i świadomość oraz zrozumienie zarówno etycznych, jak i politycznych problemów związanych z wykorzystaniem informacji”‘2.

Według Billa Johnstona i Sheili Webber kompetencje informacyjne to „umiejętność przyjęcia odpowiedniego podejścia do informacji, które pozwala na zidentyfikowanie informacji jak najlepiej dostosowanej do naszych potrzeb informacyjnych przy pomocy dowolnego kanału lub medium, prowadzące do mądrego i etycznego jej wykorzystania w społeczeństwie"43. W świetle takiej argumentacji kompetencje informacyjne są rozumiane nie tylko jako indywidualne doświadczenie potrzeby informacji i jej zaspokojenia, ale także jako doświadczenie społeczne. Autorzy przenoszą nacisk z kompetencji informacyjnej jako cechy osoby, szczególnie w kontekście edukacyjnym, na osobę z rozwi-

do 2016 r., kiedy to dn. 25 czerwca na dorocznej konferencji American Library Association w Orlando została uchylona przez zarząd ACRL. Zob. Association of College \& Research Libraries, Framework for Information Literacy for Higher Education. Chicago, 2015, http://www.ala.org/acrl/standards/ilframe-work [dostęp: 17.03.2021].

${ }^{41}$ Association of College \& Research Libraries, Framework for Information Literacy for Higher Education. Chicago, 2015, p. 8, http://www.ala.org/acrl/standards/ilframe-work [dostęp: 17.03.2021].

${ }^{42}$ CILIP, Definition Information Literacy 2018, https://infolit.org.uk/ILdefinitionCILIP2018.pdf [dostęp: 17.03.2021].

${ }^{43}$ B. Johnston, S. Webber, As we may think: Information literacy as a discipline for the information age, „Research Strategies”, 2006 t. 20, s. 108-121. 
niętą kompetencją informacyjną, którą możemy umiejscowić w dynamicznym, społecznym i osobistym kontekście społeczeństwa informacyjnego ${ }^{44}$.

Zauważając mnogość istniejących definicji kompetencji informacyjnych, należy podkreślić, że wszystkie akcentują proces przygotowania jednostki do świadomego funkcjonowania w społeczeństwie informacyjnym, stanowiąc istotny warunek radzenia sobie $\mathrm{w}$ dynamicznie zmieniającym się informacyjnym świecie, pobudzając do aktywności społecznej, uczenia się przez całe życie czy przeciwdziałając nadmiarowi informacyjnemu.

Złożoność definicji pojęcia kompetencji informacyjnych wskazują ponadto liczne modele i standardy ich kształtowania wypracowane przez wyspecjalizowane organizacje, wśród których można wymienić: ACRL (Association of College \& Research Libraries), IFLA (The International Federation of Library Associations and Institutions), ANZIL (Australian and New Zealand Institute for Information Literacy), SCONUL (Society of College, National and University Libraries) czy UNESCO. Wspólnym celem opracowanych przez nie modeli była pomoc, w jaki sposób kształcić w zakresie information literacy oraz jakie efekty powinna przynieść proponowana edukacja informacyjna. Modele i standardy opracowywane są od lat 90. tych ubiegłego wieku, jednak duży wpływ na rozwój współczesnego dyskursu dotyczącego umiejętności informacyjnych miały prace Faya V. Winkwortha, który już w 1977 roku wymienił konkretne kategorie umiejętności informacyjnych: definiowanie tematu (potrzeby informacyjnej); lokalizacja informacji; selekcja informacji; organizowanie informacji; ocena informacji i praca z uzyskanymi wynikami. Stanowią one podstawę kompetencyjną ucznia jako osoby poszukującej informacji, wśród których wyróżnić można dwie płaszczyzny kształtowania umiejętności informacyjnych: mechanizm pozyskiwania informacji ze źródeł i proces ich przetwarzania (ocena, analiza i synteza) ${ }^{45}$.

44 Tamże, s. 111.

45 F.V. Winkworth, User education in school. A survey of literature on education for library and information use in schools, London 1977, podaję za: B. Siemieniecki, Pedagogika kognitywistyczna, s. 178-179. 
Wśród modeli kształtowania information literacy można wyróżnić kompetencyjne oraz relacyjne. Podejście kompetencyjne opisuje określoną listę umiejętności, jakimi powinna legitymować się osoba uważana na kompetentną informacyjnie. Jako przykład można wskazać propozycję Christine Doyle, która wypracowała zestaw atrybutów charakteryzujących osobę przygotowaną informacyjnie. Jej zdaniem osoba posiadająca umiejętności korzystania z informacji odznacza się następującymi właściwościami: rozpoznaje potrzeby informacyjne; ma świadomość, że odpowiednia i kompletna informacja jest podstawą inteligentnego podejmowania decyzji; formułuje pytania oparte na potrzebach informacyjnych; identyfikuje potencjalne źródła informacji; buduje efektywne strategie wyszukiwawcze; uzyskuje źródła informacji, zarówno komputerowe i pozostałe; ocenia informacje; porządkuje je w celu praktycznego zastosowania; włącza nowe informacje w istniejący zasób wiedzy; wykorzystuje informacje w krytycznym myśleniu i rozwiązywaniu problemów ${ }^{46}$.

Drugi model przedstawia information literacy w kategoriach koncepcji, tzn. relacji pomiędzy obiektem a przedmiotem. Ujęcie relacyjne opracowane przez Christine Bruce koncentruje się także na właściwościach poznawczych jednostek, ale w relacji ze środowiskiem, w którym żyją. Daje wgląd w interakcje ze światem informacji tak, jak ludzie go doświadczają, pomaga także zrozumieć krytyczne różnice w doświadczeniu informacji, jak również sugeruje efekty uczenia się oparte na całokształcie doświadczeń i praktyki życiowej. Uwzględnia kontekstową naturę informacji, opierając się na założeniu, że warunkiem zdobywania kompetencji informacyjnych są doświadczenia, dotychczasowa wiedza i kontekst życiowy ${ }^{47}$. Ch. Bruce wyróżniła w swoim modelu

46 Ch. S. Doyle, Information Literacy in an Information Society: A Concept for the Information Age, ERIC Clearinghouse on Information \& Technology, Syracuse University, Syracuse, New York 1994, p. 2-3.

47 Ch. Bruce, The Seven Faces of Information Literacy, 1997, https://www.researchgate.net/publication /239229387_The_Seven_Faces_of_Information_Literacy; J. Nowak, Bibliotekarz a nauczanie kompetencji informacyjnych. Propozycje działania, „Biuletyn Biblioteki Jagiellońskiej”, 2018 R. LXVIII; E. J. Kurkowska, Edukacja informacyjna w bibliotekach a rozwój społeczeństwa wiedzy, Wydawnictwo Stowarzyszenia Bibliotekarzy Polskich, Warszawa 2012. 
siedem kategorii-obliczy (faces) postrzegania i korzystania z informacji: technologie informacyjne; źródła informacji, przetwarzanie informacji, zarządzanie informacją, tworzenie wiedzy, poszerzanie wiedzy, mądrość ${ }^{48}$. Jest to odwrotne podejście do modeli opartych na „kompetencjach", które dążą do porozumienia ekspertów co do podstawowych cech, które wyróżniają osobę posiadającą umiejętność odbioru i wykorzystania informacji. Odzwierciedla on sposób, w jaki ludzie doświadczają znajdowania i wykorzystywania informacji w kontekście, w jakim się znajdują ${ }^{49}$.

Zarysowana powyżej istota kompetencji informacyjnych kieruje uwagę na problematykę efektywnego funkcjonowania człowieka w życiu kulturalnym czy społecznym. Należy podkreślić, że osoby o wykształconych kompetencjach informacyjnych potrafią znaleźć informacje i wykorzystać je w efektywny sposób, dysponują wiedzą, jak się uczyć samodzielnie oraz są stanie tworzyć własne zasoby wiedzy. Stają się przez to ludźmi kształcącymi się przez całe życie, znajdującymi potrzebne informacje dla rozwiązania postawionego przed nimi problemu.

\section{Edukacja medialna - od teorii do praktyki edukacyjnej}

Przedstawiona w artykule idea kompetencji informacyjnych, jak również złożoność uwarunkowań współczesnego cyfrowego środowiska aktywności uczniów akcentuje konieczność aktywizacji dyskursu teoretycznego oraz intensyfikacji działań praktycznych związanych z realizacją treści mieszczących się w obszarze edukacji medialnej.

Eksperci zajmujący się problematyką kształtowania kompetencji cyfrowych (w obszarze których sytuują się kompetencje informacyjne) jednoznacznie podkreślają słabości dotychczasowego sposobu myślenia i uprawiania praktyki edukacyjnej w tym zakresie. Zwracają uwagę na rosnący dysonans pomiędzy niekontrolowaną aktywnością dzieci i młodzieży w przestrzeni cyfrowej a zbyt wolnym tempem dostosowy-

48 Ch. Bruce, The Seven Faces...

49 A. Walsh, Playful Information Literacy: Play and Information Literacy in Higher Education, "Nordic Journal of Information Literacy in Higher Education", 2015 t. 7 nr 1, s. 82. 
wania systemowych rozwiązań edukacyjnych, pedeutologicznych czy naukowo-badawczych ${ }^{50}$. Niedostatki są zauważane w

„[...] obszarze krytycznego rozumienia otoczenia medialnego, czynników kulturowych, ekonomicznych i technologicznych wpływających na korzystanie z mediów, krytycznego rozumienia zasad rządzących światem nowych mediów, używania ich w celu własnej ekspresji, zwracania uwagi na wspólnotowy i partycypacyjny charakter mediów cyfrowych, na związek kompetencji medialnych, informacyjnych i cyfrowych z kreatywnością [...], czy wreszcie na pilną potrzebę rozwijania umiejętności krytycznego myślenia" ${ }^{51}$.

Wśród znaczących dokumentów podkreślających znaczenie edukacji medialnej wymienić należy tzw. Deklarację z Fezu uchwaloną przy wsparciu UNESCO na I Międzynarodowym Forum Kompetencji Medialnej i Informacyjnej w Maroku w 2011 r. Obradujący w Fez w międzynarodowym składzie specjaliści z zakresu informatologii jako jedni z pierwszych rozpoczęli dyskusję na temat umiejętności wyszukiwania i oceny informacji pochodzących z Internetu, a kompetencje informacyjne zostały uznane za równoważne z kompetencjami medialnymi. Istotą Deklaracji z Fez stanowi przesłanie, że „w wieku rozwoju nowych technologii kompetencja medialna i informacyjna stanowi podstawowe prawo człowieka i jest niezbędnym warunkiem podnoszenia jakości życia oraz zrównoważonego rozwoju społecznego, gospodarczego i kulturalnego"52.

50 Propozycje Zespołu Pedagogiki Medialnej przy KNP PAN dla Ministerstwa Edukacji Narodowej dotyczace roli i miejsca edukacji medialnej w szkołach, http:// www.knped.pan.pl/index.php?option=com_content\&view=article \&id=219:rekomendacje-zespolu-pedagogiki-me-dla-ministerstwa-edukacji-narodowej\&ca tid=47\&Itemid=182 [dostęp: 20.03.2021].

51 A. Pacewicz, G. Ptaszek (red.), Model edukacji medialnej, informacyjnej i cyfrowej (MEMIC), Kraków-Warszawa 2019, https://fina.gov.pl/wp-content/uploads/2019/12/memic_publikacja.pdf [dostęp: 20.03.2021].

52 Fez Declaration on Media and Information Literacy, June 17, 2011, http:// www.unesco.org/new/fileadmin/ MULTIMEDIA/HQ/CI/CI/pdf/news/Fez\%20 Declaration.pdf [dostęp: 20.03.2021]. 
Edukacji medialnej nie należy utożsamiać z wyposażeniem uczniów w czysto techniczne kompetencje, umożliwiające sprawną obsługę narzędzi i aplikacji cyfrowych technologii, ale powinna się odwoływać do szerokich zagadnień dotyczących dostępu do technologii cyfrowych i źródeł informacji, ich oceny i zrozumienia oraz zdolności do krytycznej analizy i twórczego wykorzystania. Znaczenie tak rozumianych kompetencji cyfrowych wskazuje „Zalecenie Rady z dnia 22 maja 2018 r. w sprawie kompetencji kluczowych w procesie uczenia się przez całe życie", w którym czytamy, że

„kompetencje cyfrowe obejmują pewne, krytyczne i odpowiedzialne korzystanie z technologii cyfrowych i interesowanie się nimi do celów uczenia się, pracy i udziału w społeczeństwie. Obejmują one umiejętność korzystania z informacji i danych, komunikowanie się i współpracę, umiejętność korzystania z mediów, tworzenie treści cyfrowych (w tym programowanie), bezpieczeństwo (w tym komfort cyfrowy i kompetencje związane z cyberbezpieczeństwem), kwestie dotyczące własności intelektualnej, rozwiązywanie problemów i krytyczne myślenie"53.

Wśród ważnych składowych kompetencji medialnych eksperci z ramienia UNESCO wskazali dostęp; rozumienie i ocenę oraz tworzenie nowych informacji, treści medialnych lub wiedzy w określonym celu w innowacyjny, etyczny i kreatywny sposób ${ }^{54}$.

Uporządkowanie złożonych i wielowymiarowych zagadnień dotyczących kompetencji wynikających z użytkowania cyfrowych technologii przedstawia holistyczny model MEMIC. Twórcy modelu podjęli działania $\mathrm{w}$ celu zintegrowania kompetencji medialnych $\mathrm{z}$ informacyjnymi i cyfrowymi, tworząc spójną definicję edukacji medialnej, informacyjnej i cyfrowej. W myśl przedłożonej definicji, kompetencje medialne, informacyjne i cyfrowe są traktowane jako

53 Zalecenie Rady z dnia 22 maja 2018 r. w sprawie kompetencji kluczowych...

${ }^{54}$ Global Media and Information Literacy Assessment Framework: Country Readiness and Competencies, UNESCO, 2013, http://uis.unesco.org/sites/default/files/documents/global-media-and-information-literacy-assessment-framework-country-readiness-and-competencies-2013-en.pdf [dostęp: 20.03.2021]. 
„interdyscyplinarny obszar działań praktycznych, których celem jest kształcenie kompetencji, umożliwiających świadome, aktywne, odpowiedzialne, prospołeczne, krytyczne i twórcze korzystanie ze wszystkich rodzajów mediów w różnych celach. Przy czym nieodłącznym elementem takiego korzystania jest rozumienie funkcjonowania tych mediów [...] oraz ich wpływu na rozmaite obszary aktywności człowieka"55.

Takie trójdzielne ujęcie definicyjne ma - w założeniu autorów modelu - służyć wsparciem dla nauczycieli w procesie realizacji treści zorientowanych na problematykę zagadnień z zakresu technologii informacyjnej i cyfrowej.

Interesującą i uwspółcześnioną propozycję interpretowania kompetencji cyfrowych przedstawia relacyjne podejście do kompetencji cyfrowych. Uznano w nim, że kompetentne użycie mediów to takie, które podnosi jakość życia jednostki, uwzględniając jednak sposoby jej funkcjonowania $\mathrm{w}$ różnych obszarach. Wyróżnione $\mathrm{w}$ modelu relacyjnym kompetencje funkcjonalne są oparte na kompetencjach informatycznych i informacyjnych, które stanowią podłoże do realizacji konkretnych działań i osiągania korzyści dzięki stosowaniu technologii cyfrowych $^{56}$. „Kompetencje cyfrowe nie mogą stanowić celu samego w sobie, ale ich zdobywanie i kształtowanie powinno być środkiem pozwalającym na realizację różnych działań" 57 .

Dokonany powyżej przegląd koncepcji i modeli definiujących kompetencje medialne, cyfrowe i informacyjne rodzi potrzebę odszukania i analizy treści kształcenia z tego zakresu w obecnie obowiązującej podstawie programowej. Lektura zadań wskazanych na poszczególnych etapach edukacyjnych pozwala zauważyć, że ujęto zalecenia przygo-

55 A. Pacewicz, G. Ptaszek (red.), Model edukacji medialnej, s. 20.

56 J. Jasiewicz, M. Filiciak, A. Mierzecka i in., Ramowy katalog kompetencji cyfrowych, Warszawa 2015, https://cppc.gov.pl/wp-content/uploads/zal.-13-Ramowy_katalog_kompetencji_cyfrowych.pdf [dostęp: 20.03.2021].

$57 \bar{S}$. Buchholtz, A. Buchner, M. Filiciak i in., Analiza doświadczeń oraz identyfikacja dobrych praktyk $w$ obszarze wspierania rozwoju kompetencji cyfrowych $w$ kontekście przygotowania szczegółowych zasad wdrażania programu operacyjnego Polska cyfrowa na lata 2014-2020 oraz koordynacji celu tematycznego 2, Warszawa 2015, s. 14, https://www.polskacyfrowa.gov.pl/media/5180/RK_kompetencje_cyfrowe.pdf [dostęp: 20.03.2021]. 
towywania uczniów do dokonywania świadomych i odpowiedzialnych wyborów w trakcie korzystania z zasobów dostępnych w Internecie, krytycznej analizy informacji, bezpiecznego poruszania się $\mathrm{w}$ przestrzeni cyfrowej. W podstawie programowej zaznaczono, że nauczyciele wszystkich przedmiotów powinni stwarzać uczniom warunki do nabywania umiejętności wyszukiwania, porządkowania i wykorzystywania informacji z różnych źródeł oraz dokumentowania swojej pracy, z zastosowaniem technologii informacyjno-komunikacyjnych ${ }^{58}$.

Te ogólne zalecenia mieszczą się w obszarze analizowanych obszarów kompetencji medialnych, informacyjnych i cyfrowych, jednak ich udział ma charakter rozproszony i międzyprzedmiotowy. W związku z tym drogą realizacji celów z zakresu edukacji medialnej nie są treści pojedynczego, wyspecjalizowanego przedmiotu, tylko odwoływanie się do odpowiedzialności i kwalifikacji dydaktycznych każdego nauczyciela, w którego gestii spoczywać będzie możliwość kształcenia kompetencji cyfrowych uczniów. Edukacja medialna nie funkcjonuje przecież jako szkolny przedmiot kształcenia ogólnego, a treści kształcenia dotyczące problemów edukacji medialnej i informacyjnej próbuje się włączyć do programów kształcenia na wszystkich etapach edukacyjnych. Ważnym głosem w dyskusji jest tu rekomendacja ekspertów z Zespołu Pedagogiki Medialnej KNP PAN, którzy zauważają, że „kształtowanie kompetencji medialnych, informacyjnych i cyfrowych uczniów powinno odbywać się w sytuacji przywrócenia edukacji medialnej wysokiej rangi w podstawie programowej"59, zaś sposobem osiągnięcia tego postulatu czynią „precyzyjne wykorzystanie mediów oraz wiedzy o mediach we wszystkich ścieżkach przedmiotowych"60.

Warunkiem prowadzącym do wyeksponowania celów z zakresu edukacji medialnej - rozproszonych w ogólnych zadaniach szkoły

58 Rozporządzenie Ministra Edukacji Narodowej, z dn. 14 lutego 2017 r. w sprawie podstawy programowej wychowania przedszkolnego oraz podstawy programowej kształcenia ogólnego dla szkoły podstawowej, w tym dla uczniów z niepełnosprawnością intelektualną w stopniu umiarkowanym lub znacznym, kształcenia ogólnego dla branżowej szkoły I stopnia, kształcenia ogólnego dla szkoły specjalnej przysposabiającej do pracy oraz kształcenia ogólnego dla szkoły policealnej.

59 Propozycje Zespołu Pedagogiki Medialnej...

60 Tamże. 
i treściach kształcenia wybranych przedmiotów prowadzi do dyskusji nad rolą i kwalifikacjami nauczycieli. Proces zmiany metodyki kształcenia, poznanie technologii, która ma być używana, określenia celowości jej użycia w konkretnych sytuacjach dydaktycznych i wreszcie (a może przede wszystkim) mentalna zmiana w zakresie zastosowania narzędzi IT w edukacji - orientuje uwagę na osobę nauczyciela, jako podmiotu o największej mocy sprawczej w kontekście optymalizacji i efektywności procesu kształcenia z wykorzystaniem technologii cyfrowych. Wykorzystywanie w procesie kształcenia nieadekwatnych, nieskutecznych i nietrafnych w kontekście współczesnej zmiany technologiczno-kulturowej strategii nauczania jest - w opinii D. Klus-Stańskiej - efektem „inercji mentalnej”61. Ta „nieadekwatność kulturowa” jest szczególnie widoczna w obszarze kształcenia z zakresu problematyki edukacji medialnej, tym bardziej, iż proces dydaktyczny dotyczy uczniów, dla których codziennym, naturalnym środowiskiem aktywności jest przestrzeń cyfrowa. Obserwacja szkolnej rzeczywistości edukacyjnej dowodzi, że pomiędzy systemem edukacji formalnej z obszaru mediów a pozaszkolną aktywnością dzieci i młodzieży istnieje poważna luka kulturowa i obyczajowa ${ }^{62}$. W związku z tym funkcja, jaką nadamy technologiom cyfrowym w szkole, zależy w dużej mierze od koncepcji kształcenia, do której odwołają się w swojej praktyce nauczyciele. Zdaniem Michaela Fullana i Marii Langworthy:

„bez zmian w podstawowych modelach pedagogicznych, za pomocą których nauczyciele uczą, a uczniowie się uczą, inwestycje technologiczne zbyt często po prostu umacniają nieco bardziej rozrywkowe dostarczanie treści lub podstawowe umiejętności praktyczne na konwencjonalne strategie nauczania, które koncentrują się na odtwarzaniu istniejącej wiedzy"63.

61 D. Klus-Stańska, Wiedza, która zniewala - transmisyjne tradycje w szkolnej edukacji, „Forum Oświatowe”, 2012 nr 1, s. 36.

62 Zob. A. Ogonowska, Kompetencje medialne i informacyjne: wybrane modelowe ujęcia i koncepcje, „Zeszyty Prasoznawcze”, 2015 nr 1.

63 M. Fullan, M. Langworthy, A Rich Seam: How New Pedagogies Find Deep Learning, http://www.michaelfullan.ca/wp-content/uploads/2014/01/3897.Rich_ Seam_web.pdf, London 2014, s. 30, [dostęp: 20. 04. 2018]. 
Ilustracją powyżej opinii mogą służyć wyniki badania „Polska szkoła w dobie cyfryzacji. Diagnoza 2017”, które wskazują, że obraz polskiej szkoły w kontekście wykorzystania technologii cyfrowych tworzą „zaawansowani cyfrowo uczniowie, ciekawi nowych możliwości, lecz nieufni wobec technologii w szkole rodzice oraz nauczyciele słabo wyposażeni przez swoje placówki w odpowiednie narzędzia oraz cyfrowe kompetencje"64. Badania zespołu naukowców z Uniwersytetu Warszawskiego odsłoniły, że nauczycielom wyraźnie brakowało „rzetelnej wiedzy z zakresu nowoczesnej neurodydaktyki i kompetencji w projektowaniu zajęć, które sprzyjałyby konstruowaniu wiedzy przez uczniów w wyniku własnej aktywności eksploracyjnej i intelektualnej”65. Sytuację tę tym bardziej dobitnie ukazuje analiza trudności, z jakimi musieli się zmierzyć na nauczyciele w obliczu konieczności realizacji edukacji $\mathrm{w}$ trybie zdalnym z powodu pandemii koronawirusa. Analiza wykorzystywanych strategii i modeli kształcenia w perspektywie przed lockdownem oraz w trakcie kształcenia zdalnego wskazała przywiązanie nauczycieli do metod podających (opartych na obserwacji i słowie) oraz mniejsze wykorzystanie metod aktywizujących uczniów oraz stymulujących ich do pracy w zespołach w trybie online ${ }^{66}$. Jak słusznie podkreślają autorzy jednego z badań:

„niewłaściwe przygotowanie nauczycieli do edukacji zdalnej oraz niski poziom kompetencji cyfrowych przełożył się na stosowane przez nich sposoby pracy i metody dydaktyczne oraz wykorzystywane narzędzia umożliwiające kształtowanie określonych kompetencji cyfrowych uczniów"67.

64 M. Plebańska, M. Sieńczewska, A. Szyller (red.), Polska szkoła $w$ dobie cyfryzacji. Diagnoza 2017. Warszawa, 2017, s. 8. https://www.cyfrowobezpieczni.pl/ uploads/filemanager/raporty/RAPORT_CYFRYZCJA_SZKOL_2017.pdf [dostęp: 12.11.2020].

65 Tamże, s. 23.

66 G. Ptaszek, G.D. Stunża, J. Pyżalski, M. Dębski, M. Bigaj, Edukacja zdalna. Co się stało z uczniami, ich rodzicami i nauczycielami?, Gdańsk 2020, s. 66, https://zdalnenauczanie.org/wp-content/uploads/2020/10/edukacja-zdalna.pdf [dostęp: 20.03.2021].

67 Tamże, s. 61. 
Pandemia COVID-19 unaoczniła nie tylko wagę odpowiednich kompetencji cyfrowych nauczycieli, ale także wzmocniła przeświadczenie o konieczności znajomości nowoczesnej strategii kształcenia, budowanej na podłożu idei kognitywistycznych i konstruktywistycznych, wymagających odmiennej organizacji i modelu pracy nauczyciela $\mathrm{z}$ uczniem ${ }^{68}$. Ramy artykułu nie pozwalają na uszczegółowienie założeń wskazanych teorii, ale ich wspólną cechą jest orientacja procesu edukacji na samodzielność poznawczą ucznia i odmienny rodzaj aktywności, w rezultacie której „wiedza konstruowana przez ucznia będzie jak najbardziej dla niego znacząca, pogłębiona, systemowa, dynamiczna i elastyczna"69.

\section{Zakończenie}

Potrzeba wypracowania postawy krytycznej wobec nadmiaru informacji, jak i umiejętności odpowiedzialnego funkcjonowania w świecie mediów cyfrowych wydają się być najważniejszymi celami edukacji medialnej. Niewystarczający poziom kształcenia z tego zakresu grozi ryzykiem cyfrowego wykluczenia uczniów, prowadzącym do narażenia się na procesy perswazji i manipulacji informacjami zniekształconymi czy przekłamanymi, jak również uleganiu złudzeniu, że wszystko to, co znajduje się w sieci jest prawdziwe i rzetelne. W sytuacji często jedynie teoretycznej obecności postulatów kształcenia kompetencji medialnych, informacyjnych i cyfrowych uczniów ważną formą ich zdobycia może pozostać proces samoedukacji uczniów. Mimo niewątpliwe ważności samokształcenia uczniów, nie można tego procesu zaakceptować jako wystarczający. Praktyczna realizacja celów z obszaru edukacji medialnej

68 Zob. D. Klus-Stańska, Paradygmaty współczesnej dydaktyki. Myśleć teoria o praktyce, Warszawa 2018; M. Tanaś, Kształcenie komplementarne na poziomie akademickim. Kontekst dydaktyczny i informatyczny, „Heteroglossia. Studia Kulturoznawczo-Filologiczne", 2011 nr 1; B. Siemieniecki, Pedagogika kognitywistyczna; B. Siemieniecki (red.), Pedagogika medialna, tom 1, Warszawa 2008; D. Siemieniecka, B. Siemieniecki, Teorie kształcenia w świecie cyfrowym, Kraków 2019; L. Daniela, Smart Pedagogy for Technology-Enhanced Learning, w: red. L. Daniela, Didactics of Smart Pedagogy, Springer 2019.

69 D. Klus-Stańska, Paradygmaty współczesnej dydaktyki, s. 137. 
jest - jak wskazałam wyżej - równoznaczna z koniecznością redefiniowania dotychczasowej filozofii kształcenia w obrębie wszystkich dydaktyk szczegółowych, gdyż troska o proces wychowania informacyjnego powinna być doświadczana przez nauczyciela każdego przedmiotu.

W kontekście analizowanych w tekście problemów wynikających z realizacji celów edukacji medialnej najbardziej znaczącym staje się wsparcie uczniów przez kompetentnego nauczyciela, sprawnego w zakresie cyfrowej kultury. Profesjonalizm cyfrowy nauczyciela pozwala inaczej postrzegać i odbierać obecność mediów jako środków dydaktycznych w procesie kształcenia. Ich pozycja i ranga zmienia się z elementów „odświętnych”, „unowocześniających” lekcję, „sztucznych” czy „okazjonalnych” na zasoby codzienne, naturalne i powszechne, stale obecne w życiu pozaszkolnym uczniów. Nie można przy tym zapominać, że technologie cyfrowe są dla uczniów przestrzenią pozbawioną barier, lęków czy uprzedzeń, które dla nauczycieli z kolei często stanowią blokadę utrudniającą ich wykorzystywanie. Z drugiej strony - brak zahamowań ze strony uczniów w posługiwaniu się przestrzenią wirtualną niestety nie jest równoznaczne z poprawną formą i sposobem jej użytkowania. Często bowiem nowe technologie są eksplorowane przez młodocianych użytkowników w sposób powierzchowny, spłycony, czy nierzadko niebezpieczny lub wręcz patologiczny. Konfrontacja niepewności nauczyciela i jego niewystarczających kompetencji cyfrowych $\mathrm{z}$ naturalnością $\mathrm{w}$ traktowaniu cyfrowych technologii przez uczniów niestety nie może sprzyjać dynamice realizacji celów edukacji medialnej. Z drugiej strony nie można także generalizować i ulegać stereotypom o wybitnych zdolnościach medialnych młodego pokolenia oraz zapóźnieniach technologicznych wszystkich nauczycieli. Nie ulega jednak wątpliwości, że wykorzystanie mediów w procesie kształcenia, a tym samym aktywizowanie celów i treści z zakresu kształcenia medialnego musi nastąpić w warunkach świadomego, a nie przypadkowego użycia narzędzi technologicznych na lekcjach każdego przedmiotu przez nauczyciela świadomego ich znaczenia i potencjału edukacyjnego.

Dzięki jego profesjonalnym umiejętnościom cyfrowym edukacja wspomagana narzędziami cyfrowymi może stać się przyczynkiem do rozwoju wielu sfer uczniów. Wysoko rozwinięte kompetencje informacyjne, których kształcenie jest jednym z zadań edukacji medialnej, 
warunkują jakość życia społecznego uczniów w dorosłości, ułatwiając wartościowanie informacji i krytyczną refleksję w procesie ich przetwarzania. Umiejętność interpretacji, wykorzystania i twórczych działań obejmujących informację otwiera drogę do budowania struktur wiedzy i kształtowania mądrości, a co ważne, również pomaga uczniom stawać się świadomym odbiorcą i kreatywnym twórcą treści w sieciowych społecznościach.

\section{Bibliografia:}

Association of College \& Research Libraries, Framework for Information Literacy for Higher Education. Chicago, 2015. http://www.ala.org/acrl/standards/ilframe-work.

Babik, Wiesław. „O natłoku informacji i związanym z nim przeciążeniu informacyjnym". W: Człowiek, media, edukacja, red. Janusz Morbitzer, 21-27. Kraków: Katedra Technologii i Mediów Edukacyjnych Uniwersytetu Pedagogicznego im. KEN w Krakowie, 2010.

Badke, Wiliam. Foundations of Information Literacy: Learning From Paul Zurkowski, 2010: 48-50. https://www.researchgate.net/publication/293703989_ Foundations_of_information_literacy_Learning_from_paul_zurkowski.

Batorowska, Hanna, Rafał Klepka, Olga Wasiuta, Media jako instrument wptywu informacyjnego i manipulacji społeczeństwem. Kraków: Libron, 2019.

Bąkowicz, Katarzyna. „Wprowadzenie do definicji i klasyfikacji zjawiska fake newsa", Studia Medioznawcze 3 (2019): 280-289.

Big Data - duże liczby, nowe możliwości, nowe narzędzia. https://skuteczneraporty.pl/blog/big-data-duze-liczby-nowe-mozliwosci-nowe-narzedzia.

Bochenek, Marcin, Rafał Lange. Bezpieczne wybory. Badanie opinii o (dez)informacji $w$ sieci. Warszawa: NASK Państwowy Instytut Badawczy 2019. https:// www.nask.pl/pl/o-nask/eksperci-nask/publikacje-naukowe/1631,BadaniaNASK-ponad-polowa-Polakow-styka-sie-z-manipulacja-i-dezinformacja-w-in te.html.

Bruce, Christine S. The Seven Faces of Information Literacy, 1997. https://www. researchgate.net/publication/239229387_The_Seven_Faces_of_Information_Literacy. 
Buchholtz, Sonia, Anna Buchner, Mirosław Filiciak i in., Analiza doświadczeń oraz identyfikacja dobrych praktyk $w$ obszarze wspierania rozwoju kompetencji cyfrowych $w$ kontekście przygotowania szczegółowych zasad wdrażania programu operacyjnego Polska cyfrowa na lata 2014-2020 oraz koordynacji celu tematycznego 2, Warszawa: Warszawski Instytut Studiów Ekonomicznych i Centrum Cyfrowe Projekt: Polska, 2015. https://www.polskacyfrowa.gov.pl/media/5180/RK_kompetencje_cyfrowe.pdf.

CILIP, Definition Information Literacy 2018. https://infolit.org.uk/ILdefinitionCILIP2018.pdf.

Collins 2017 Word of the Year Shortlist. https://blog.collinsdictionary.com/ language-lovers/collins-2017-word-of-the-year-shortlist.

Daniela, Linda. Smart Pedagogy for Technology-Enhanced Learning. W: Didactics of Smart Pedagogy, red. Linda Daniela, 3-21. Springer, 2019.

Doyle, Christina S. Information Literacy in an Information Society: A Concept for the Information Age, Syracuse, New York: ERIC Clearinghouse on Information \& Technology, Syracuse University, 1994.

Drucker, Peter. Zarządzanie w XXI wieku. Warszawa: Muza, 2000.

Fez Declaration on Media and Information Literacy, 2011. http://www.unesco. org/new/fileadmin/MULTIMEDIA/HQ/CI/CI/pdf/news/Fez\%20Declaration.pdf.

Filiciak, Mirosław, Michał Danielewicz, Mateusz Halawa, Paweł Mazurek, Agata Nowotny. Młodzi i media. Nowe media a uczestnictwo $w$ kulturze, Warszawa: Raport Centrum Badań nad Kulturą Popularną SWPS, 2010. https://www.swps.pl/images/stories/dokumenty/RAPORT_SWPS_mlodzi_i_media.pdf.

Fulgoni, Gian, Andrew Lipsman. "The Downside of Digital Word of Mouth and the Pursuit of Media Quality". Journal of Advertising Research 57 (2017): 127-131.

Fullan, Michael, Maria Langworthy, A Rich Seam: How New Pedagogies Find Deep Learning. http://www.michaelfullan.ca/wp-content/uploads/2014/01/3897. Rich_Seam_web.pdf, London: Pearson, 2014.

Gleick, James. Informacja, bit, wszechświat, rewolucja. Tłum. Grzegorz Siwek Kraków: Wydawnictwo Znak, 2012.

Global Media and Information Literacy Assessment Framework: Country Readiness and Competencies. UNESCO 2013. http://uis.unesco.org/sites/default/files/documents/global-media-and-information-literacy-assessmentframework-country-readiness-and-competencies-2013-en.pdf. 
Goban-Klas, Tomasz. „Surfowanie czy żeglowanie w cyberprzestrzeni, czyli o wychowaniu człowieka medialnego i mobilnego". W: Polskie doświadczenia $w$ kształtowaniu społeczeństwa informacyjnego: dylematy cywilizacyjno-kulturowe, red. Lesław Haber, 40-48. Kraków: Wydawnictwo AGH, 2002.

Goban-Klas, Tomasz. 2020. „Media w płynnej pandemii 2020. Komunikacja w czasie lockdownu: oddzielnie, ale razem". Studia Medioznawcze 4: 718-733. DOI: https://doi.org/10.33077/uw. 24511617.ms.2020.4.288.

Jackson, Maggie. Distracted: The Erosion of Attention and the Coming Dark Age, New York: Amherst, Oxford: Prometheus Books, 2008.

Jasiewicz, Justyna, Mirosław Filiciak, Anna Mierzecka i in., Ramowy katalog kompetencji cyfrowych, Warszawa 2015. https://cppc.gov.pl/wp-content/ uploads/zal.-13-Ramowy_katalog_kompetencji_cyfrowych.pdf.

Jemielniak, Dariusz. Socjologia Internetu. Warszawa: Wydawnictwo Naukowe Scholar, 2019.

Johnston, Bill, Sheila Webber, "As we may think: Information literacy as a discipline for the information age", Research Strategies 20 (2006): 108-121.

Klus-Stańska, Dorota. „Wiedza, która zniewala - transmisyjne tradycje w szkolnej edukacji", Forum Oświatowe 1 (2012): 21-40.

Klus-Stańska, Dorota. Paradygmaty współczesnej dydaktyki. Myśleć teoriq o praktyce. Warszawa: PWN, 2018.

Kurkowska, Ewa J., Edukacja informacyjna w bibliotekach a rozwój społeczeństwa wiedzy, Warszawa: Wydawnictwo Stowarzyszenia Bibliotekarzy Polskich, 2012.

Ledzińska, Maria. „Rola inteligencji poznawczej i emocjonalnej w dobie nadprodukcji informacji”. Annales Universitatis Mariae Curie-Skłodowska Lublin-Polonia vol. XVIII, Sectio J (2005): 13-22.

Loska, Krzysztof, Dziedzictwo McLuhana - między nowoczesnościq a ponowoczesnościq̨. Kraków: Wydawnictwo Rabid, 2001.

Nowak, Jagoda. 2012. „Bibliotekarz a nauczanie kompetencji informacyjnych. Propozycje działania". Biuletyn Biblioteki Jagiellońskiej LXVIII. DOI: 10.26106/x63h-xr51.

Nowina-Konopka, Maria, Infomorfoza. Zarzq̨dzanie informacją $w$ nowych mediach. Kraków: Wydawnictwo Uniwersytetu Jagiellońskiego, 2017.

Ogonowska, Agnieszka. 2015. „Kompetencje medialne i informacyjne: wybrane modelowe ujęcia i koncepcje". Zeszyty Prasoznawcze 1: 72-88. DOI: 10.4467/2299-6362PZ.15.006.3144.

Orliński, Wojciech. Internet. Czas się bać. Warszawa: Agora, 2013. 
Pacewicz, Alicja, Grzegorz Ptaszek (red.), Model edukacji medialnej, informacyjnej i cyfrowej (MEMIC), Kraków-Warszawa: Centrum Edukacji Obywatelskiej, Filmoteka Narodowa - Instytut Audiowizualny, Fundacja Nowoczesna Polska Fundacja Szkoła z Klasą, Polski Komitet do spraw UNESCO, Polskie Towarzystwo Edukacji Medialnej, Stowarzyszenie Cyfrowy Dialog, 2019. https://fina.gov.pl/wp-content/uploads/2019/12/memic_publikacja.pdf.

Pariser, Eli. Uważaj na internetowe „bańki filtrujące”. https://www.ted.com/talks/ eli_pariser_beware_online_filter_bubbles/transcript?language=pl\#t-9105.

Plebańska, Marlena, Małgorzata Sieńczewska, Aleksandra Szyller (red.), Polska szkoła $w$ dobie cyfryzacji. Diagnoza 2017. Warszawa, 2017. https:// www.cyfrowobezpieczni.pl/uploads/filemanager/raporty/RAPORT_CYFRYZCJA_SZKOL_2017.pdf.

Ptaszek, Grzegorz, Grzegorz D. Stunża, Jacek Pyżalski, Maciej Dębski, Magdalena Bigaj, Edukacja zdalna. Co się stało z uczniami, ich rodzicami i nauczycielami? Gdańsk: Gdańskie Wydawnictwo Psychologiczne, 2020. https:// zdalnenauczanie.org/wp-content/uploads/2020/10/edukacja-zdalna.pdf.

Rozporządzenie Ministra Edukacji Narodowej, z dnia 14 lutego 2017 r. w sprawie podstawy programowej wychowania przedszkolnego oraz podstawy programowej kształcenia ogólnego dla szkoły podstawowej, w tym dla uczniów z niepełnosprawnością intelektualną w stopniu umiarkowanym lub znacznym, kształcenia ogólnego dla branżowej szkoły I stopnia, kształcenia ogólnego dla szkoły specjalnej przysposabiającej do pracy oraz kształcenia ogólnego dla szkoły policealnej.

Siemieniecka, Dorota, Bronisław Siemieniecki, Teorie kształcenia $w$ świecie cyfrowym, Kraków: Impuls, 2019.

Siemieniecki, Bronisław (red.), Pedagogika medialna, tom 1, Warszawa: PWN, 2008.

Siemieniecki, Bronisław. Pedagogika kognitywistyczna. Studium teoretyczne. Kraków: Impuls, 2013.

Simon, Herbert. 1971. "A Designing Organizations for an Information-Rich World". In: Computers, Communications, and the Public Interest, eds. Martin Greenberger, 37-72. Baltimore: The Johns Hopkins Press. https://zeus.zeit. de/2007/39/simon.pdf.

Spitzer, Manfred. Cyfrowa demencja. Słupsk: Wydawnictwo Dobra Literatura, 2013.

Stefanowicz, Bogdan. Informacja. Warszawa: Oficyna Wydawnicza SGH, 2010. 
Szpunar, Magdalena. Kultura algorytmów. Kraków: Instytut Dziennikarstwa, Mediów i Komunikacji Społecznej Uniwersytetu Jagiellońskiego, 2019.

Światowiec-Szczepańska, Justyna. 2018. „Zjawisko przeciążenia informacyjnego w procesach decyzyjnych menedżerów". Studia Oeconomica Posnaniensia vol. 6, no. 11: 60-78. DOI: http://dx.doi.org/10.18559/SOEP.2018.11.4.

Tanaś, Maciej. „Kształcenie komplementarne na poziomie akademickim. Kontekst dydaktyczny i informatyczny". Heteroglossia. Studia Kulturoznawczo-Filologiczne 1 (2011): 95-106.

Twenge, Jean M. iGen. Sopot: Smak Słowa, 2019.

Walsh, Andrew, "Playful Information Literacy: Play and Information Literacy in Higher Education", Nordic Journal of Information Literacy in Higher Education 1 (2015): 80-94.

Waszak, Marcin. 2017. „Postprawda i fake news”. Refleksje 6: 173-188. http:// refleksje.amu.edu.pl/wp-content/uploads/2018/07/re_2017_16_12.pdf. DOI: $10.14746 /$ r.2017.2.13.

Wenta, Kazimierz. „Meandry zaufania do Internetu w nieprzychylnym świecie". W: Człowiek, media, edukacja, red. Janusz Morbitzer, Emila Musiał, 434-439. Kraków: Katedra Technologii i Mediów Edukacyjnych Uniwersytetu Pedagogicznego im. KEN w Krakowie, 2013.

Williams, Peter, Ian Rowlands. Information behaviour of the researcher of the future, 2007. https://edu.au.dk/fileadmin/www.dpu.dk/viden/temaeraaa/informationskompetence/subsites_informationskompetence20100223144624_information-behaviour.pdf.

Zalecenie Rady Unii Europejskiej z dnia 22 maja 2018 r. w sprawie kompetencji kluczowych w procesie uczenia się przez całe życie. https://eur-lex.europa.eu/legal-content/PL/TXT/PDF/?uri=CELEX: 32018H0604(01)\&fro$\mathrm{m}=\mathrm{EN}$.

Zespół Pedagogiki Medialnej przy KNP PAN, Propozycje Zespołu Pedagogiki Medialnej przy KNP PAN dla Ministerstwa Edukacji Narodowej dotyczace roli $i$ miejsca edukacji medialnej $w$ szkołach. http://www.knped.pan.pl/ index.php?option=com_content\&view=article\&id=219:rekomendacje-zespolupedagogiki-me-dla-ministerstwa-edukacji-narodowej\&catid=47\&Itemid=182.

Zwalczanie dezinformacji $w$ Internecie: podejście europejskie, Komunikat Komisji do Parlamentu Europejskiego, Rady, Europejskiego Komitetu Ekonomiczno-Społecznego i Komitetu Regionów, 2018. http://data.consilium.europa.eu/doc/document/ST-8578-2018-INIT/pl/pdf. 